\title{
Joanna Domagała
}

Warsaw University of Life and Sciences e-mail: joanna_domagala@sggw.edu.pl ORCID: 0000-0001-9801-4344

\section{LINKS BETWEEN THE PRICE OF BUTTER IN POLAND AND IN SELECTED FOREIGN MARKETS}

DOI: $10.15611 / \mathrm{pn} .2021 .3 .02$

JEL Classification: Q11, Q13, L66

\section{(C) 2020 Joanna Domagała}

This work is licensed under the Creative Commons Attribution-ShareAlike 4.0 International License. To view a copy of this license, visit http://creativecommons.org/licenses/by-sa/4.0/

Quote as: Domagała, J. (2021). Links between the price of butter in Poland and in selected foreign markets. Prace Naukowe Uniwersytetu Ekonomicznego we Wroctawiu, 65(3).

\begin{abstract}
The aim of the paper was to determine the links between price of butter in Poland and in other selected countries. The article used secondary data for the monthly price of butter at country level collected by the Milk Market Observatory and the Italian Dairy Economic Consulting Portal for 2000-2017. The analyses covered two periods: 2000-2007 and 2008-2017. The article used the Johansen cointegration tests, and Granger's causality analysis. The analyses in the first stage concerned the links between butter prices in Poland and those in Western Europe, the USA and Oceania. In the second stage, the links between butter prices in Poland and selected EU countries were identified. The results confirmed the stronger link between the price of butter in Poland and in Western Europe and Oceania. It is worth noting that this occurred mainly in the period after the financial crisis. Within the EU, butter prices in Belgium, the Czech Republic, Germany, Ireland and the Netherlands were strongly related to the price in Poland.
\end{abstract}

Keywords: butter market, price, time series analysis.

\section{Introduction}

Prices constitute a fundamental category in economics, and their changeability is a part of their essence (an attribute of the functioning of a competitive market). In a micro-economic approach, the price mechanism is used for equilibrium models. A simple analysis of the law of demand and supply, as well as the effect of non-price factors, allow for concluding that as goods become rarer, their prices increase, which limits their consumption and forces changes on the side of supply (Szajner, 2017). The efficiency of this system is significantly limited when it comes to movements in 
prices, which are unpredictable. Therefore the changeability of prices demonstrates by how much, in what period, and in what directions prices are changing. An important issue is the analysis of the determinants of price transmission in three basic sections: as part of vertically integrated market channels, over time, and in terms of space (Rembeza, 2009).

An analysis of the links between prices and their transmission between markets, separated in terms of space, has long been the subject of multiple theoretical and empirical works (Rembeza, and Chotkowski 2006). The most common theoretical structure describing these relationships is the Law of One Price (LOP), according to which price differences between markets should not exceed the costs connected with the transfer of a product. Then, the testing of the behaviour of prices using a method postulated by the theory becomes the subject of empirical studies. Such studies are difficult due to methodological challenges (Baulch, 1997). There may occur situations in which, for example, over a short period of time, prices do not perform in a manner entirely consistent with LOP, while such consistency may be maintained in a longer period (Baffes and Bruce, 2003).

A time series analysis of prices may be used for testing the integration of a market and determining its spatial boundaries. This was noted by A. Marshall in his definition of the term 'market', who argued that "the more nearly perfect a market is, the stronger is the tendency for the same price to be paid for the same thing at the same time in all parts of the market" (Werden and Froeb, 1993, p. 329). T. Mickiewicz also emphasised that, on the market of a given commodity, the condition of uniform price should be met (Mickiewicz, 2012, p. 68). However, in spite of the key importance of market boundaries, a breakthrough in solving this issue with the use of quantitative tests started as late as the turn of the 1970s and 1980s (Werden and Froeb, 1993; Massey 2000). Analyses with the use of diverse methods can be found in particular in anti-monopoly and anti-dumping proceedings (Office for Competition and Consumer Protection, 2014).

One area of research popular in recent years is the analysis of the causal links on agricultural markets (Krawiec, 2013). Poland's accession to the EU significantly changed the functioning of the national agricultural markets, including price levels and price changes. Two phenomena appeared: the alignment of the average level of prices to the EU market, and the increase of the strength of response of prices on the Polish market to price changes on EU markets.

The analysis of casual relations in the milk market was carried out by, among others, Rembeza, Seremak-Bulge and Hryszko (2005); Katrakilidis (2008); Bakucs, Fałkowski and Fertö (2010); Jha, Singh and Singh (2012); Fousekis, Emmanouilides and Grigoriadis (2016), Fousekis and Trachanas (2016), Seremak-Bulge, Roman (2016), Zhang, Brown, Dong and Waldron (2017), Baran (2019) and Domagała $(2019,2020)$.

As a result of the processes of internationalisation and globalisation, geographically distant areas can influence the milk processing sector in Poland, and vice versa. The impact of global markets on the Polish market of dairy products can 
be effected, for example, through prices. Furthermore, in accordance with the adopted demand-supply approach to defining a market/sector, the decisions of buyers and sellers on a given market are mutually agreed upon through prices. Therefore, prices are both a resultant and a regulator of the relations between the demand and supply sides of the market (Szajner, 2017, p. 4). The identification of the links between prices, their transmission and the changes between geographically distant markets can illustrate the reach of the processes of internationalisation and globalisation of a given sector.

Thus, the aim of the article was to analyse price transmission in the context of time and space in order to identify the links between the prices of butter in Poland and in the selected countries.

\section{Material and methods}

In order to determine the links between the prices of butter in Poland and in selected countries, secondary data - collected by Italian Dairy Economic Consulting (CLAL. IT) and the European Milk Market Observatory (EU MMO) - on the country's monthly price of butter were used.

The research consisted of two stages. In the first stage, the links between the price of butter in Poland and in Western Europe, the US and Oceania were analysed. The choice of foreign markets was intentional, as Western and Central Europe, North America (excluding Mexico) and Oceania, form the "Triad" of the world's dairy industry, which is characterised by high production and consumption of milk per capita. Production in these regions accounts for $35 \%$ of total output and is higher than consumption, as confirmed by high self-sufficiency rates. What is more, these regions have a large share in global trade. In 2016, their total share in the volume of dairy exports was approximately $85 \%$, and imports - around $60 \%$. These are also known as places where numerous global dairy companies originated from, which through direct foreign investment have expanded their businesses into other regions.

In the second stage of the study, the links between butter prices in Poland and selected EU countries were determined. The analysed period was 2004-2017 (subject to data availability). For the analysis of price linkage, nine EU countries were selected, and their selection was determined by the data availability for the whole analysed period.

All the analyses were conducted for the entire 2000-2017 (global market) and the 2004-2017 (EU markets) periods. Additionally, as part of the global price analyses, research for two intentionally separated sub-periods was also carried out. While determining the sub-periods, the global financial crisis was taken into account, thus for the purposes of the global market analysis, the following sub-periods were distinguished: 2000-2007 and 2008-2017. It should be noted that in the second period (after the global financial crisis) prices showed converging movements (Figures 1, 2, and 3) and correlation occurred between the price of butter in Poland and in other countries. Moreover the second period of analysis is related to the reforms of the 
Common Agricultural Policy (CAP), whose aim was to liberalise the milk market and support its exposure to the global market.

Due to the fact that the analysed time series were more multiplicative than additive and that the least squares method was used, the calculations were based on logarithmic data. The time series transformation caused the volatility amplitude to remain at approximately the same level (Hamulczuk, 2007; Seremak-Bulge, and Roman, 2016). The time series were also cleared of seasonal variations using the X-12 ARIMA method in the GRETL program ${ }^{1}$.

In order to determine the long-term link between prices in Poland and the world/ EU, a cointegration analysis was performed, based on Johansen's method. However, in the analysis of the short-term link between butter prices in Poland and the world/ EU - the Granger causality test was used.

The cointegration analysis focused on the links between butter prices in Poland and the world/EU, and enabled to identify false-positive links and determine whether there was a certain balance between the price series, in which deviations tend to be zero. These deviations are short-term in nature and do not determine the long-term link between the prices. Non-stationary variables that demonstrate such links are called cointegrated variables.

Johansen's test aimed at estimating the model of vector autoregression (Czapla, 2010, p. 268):

$$
\Delta x_{t}=\prod x_{t-1}+\sum_{i=1}^{k-1} \Gamma_{i} x_{t-1}+\Phi D_{t}+\varepsilon_{t} .
$$

It also aimed at the estimation of maximum likelihood, determination of $\Pi$ matrix's eigenvalues and verification of non-zero eigenvalues. In addition, Johansen's method involved testing with unrestricted intercepts and restricted trends. Trace statistics and maximum values were used to test the cointegration.

However, in the analysis of the short-term link between SMP prices in Poland and the world/EU, the Granger causality test was used. According to this method: "Variable $\mathrm{X}$ is said to Granger-cause variable $\mathrm{Y}$ if the current $\mathrm{Y}$ values are better explained using lagged and current $\mathrm{X}$ values than without them" (Hamulczuk, Gędek, Klimkowski, and Stańko, 2012, p. 54). The causality was examined based on the following test (Hamulczuk, and Klimkowski, 2011):

$$
y_{t}=A_{0} D_{t}+\sum_{j=1}^{k} \alpha_{j} y_{t-1}+\sum_{j=1}^{k} \beta_{j} x_{t-1}+\varepsilon_{t}
$$

where: $A_{0}, \alpha_{j}, \beta_{j}$ - model parameters, $D_{t}-$ deterministic variables, $y$ and $x$ are the analysed model variables, $k-$ lags.

${ }^{1}$ The deseasonisation procedure was implemented in the GRETL program. The time series were deseasonised because the prices of dairy products are characterised by seasonality. 
If $\beta 1=\beta 2=\ldots=\beta \mathrm{k}=0$, thus the $\mathrm{X}$ variable is not the Granger-cause of the $\mathrm{Y}$ variable. In contrast, if the $\mathrm{X}$ variable is the cause of the $\mathrm{Y}$ variable and the $\mathrm{Y}$ variable is the cause of the $\mathrm{X}$ variable, then there is a mutual causation. To verify this hypothesis, the Fisher-Sendecor test was used (Charemza and Deadman, 1997).

\section{Results}

Butter, next to powdered milk and cheese, occupies a significant position in the structure of trade in dairy products. In world exports and imports of dairy products, butter constitutes 5\%, and in Polish exports and imports, $8 \%$ and $7 \%$, respectively. The European butter market has undergone relatively big changes in recent years. Since 2014, a drop in production was caused by Russia's embargo on food produced in the European Union, which used to make up as much as a quarter of exports. Prices of butter decreased, leading to a reduction in production. Meanwhile, however, the demand for butter increased which was partly caused by an increased interest on the Asian market, as well as the dispelling of the myth about butter's negative effect on health, combined with increased consumer awareness.

For some time, the largest producer of butter in the European Union has been Germany (488,000 tonnes in 2017), followed by France (415,000 tonnes) and Ireland $(274,000)$. Poland ranks fifth, with the production of 214,000 tonnes.

Currently the largest importers of European butter include the USA $(27,000$ tonnes in 2017), Saudi Arabia (10,000 tonnes) and China (8,000 tonnes). Total exports from the EU in 2016 were 162,000 tonnes, which, however, dropped by $15 \%$ to 137,000 tonnes in 2017. In turn, the largest quantities of butter imported to the European Union come from New Zealand (5,500 tonnes in 2017) and Ukraine (2,000 tonnes). Over the last two decades, prices of butter have varied significantly. Particularly high prices were recorded in 2007-2008, 2011-2012, 2013-2014 and 2016-2017. Price peaks and troughs in Poland were consistent with their counterparts on the European and Oceanic markets in the same periods, which may confirm the links between the markets (Figures 1, 2, and 3).

In order to determine the strength of the long-term links, an analysis of the cointegration of butter prices was conducted to determine whether there is a certain equilibrium between the price series that would indicate that the variables are cointegrated with each other. As part of the conducted long-term analyses, links were confirmed only between the prices of butter in Poland and prices of butter in Oceania (Table 1). The price of butter in Poland did not show any long-term links with those in Western Europe and the USA in any period.

Apart from the determination of a mutually co-integrated time series of prices of butter, the direction of price impulse transmission between areas is also significant. The Granger causality test was used for analysing this issue (Table 2). The analysis showed that in the entire studied period, the price of butter in Poland was affected most by butter prices in Western Europe. This confirms the previous analyses by 


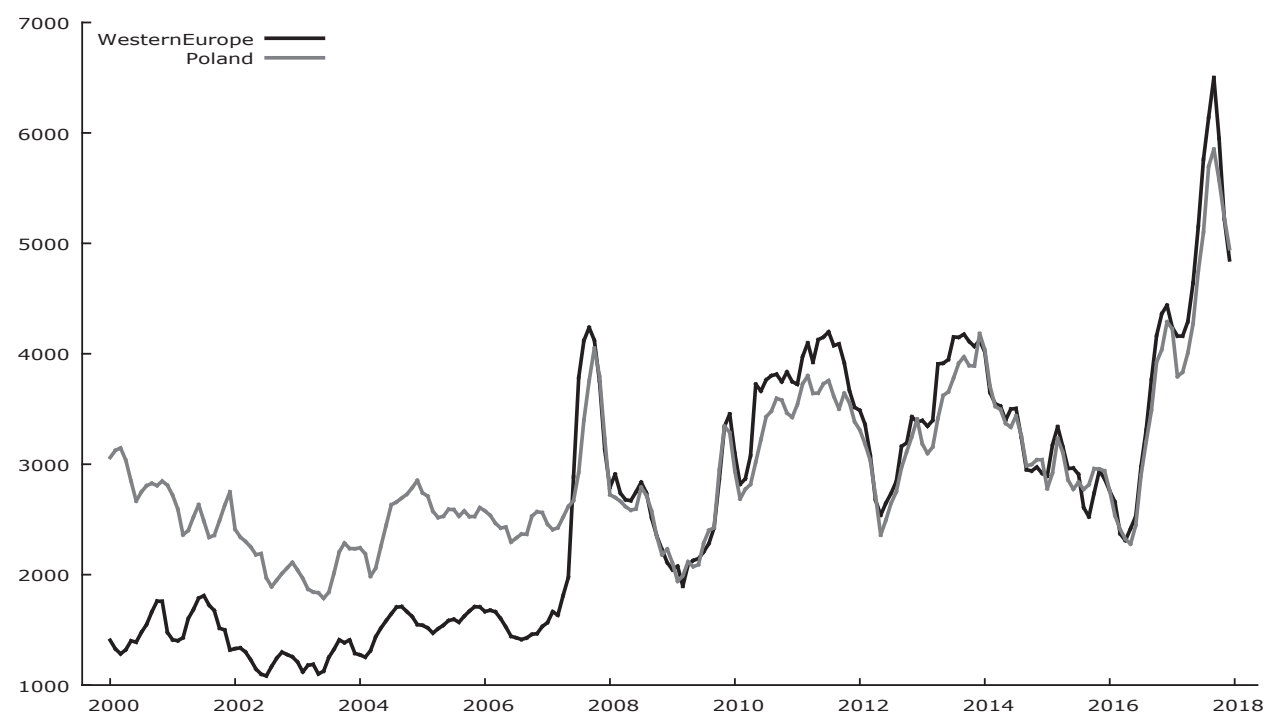

Fig. 1. Prices of butter in Poland and Western Europe in 2000-2017 (€/tons)

Source: own work based on (CLAL.IT, n.d.).

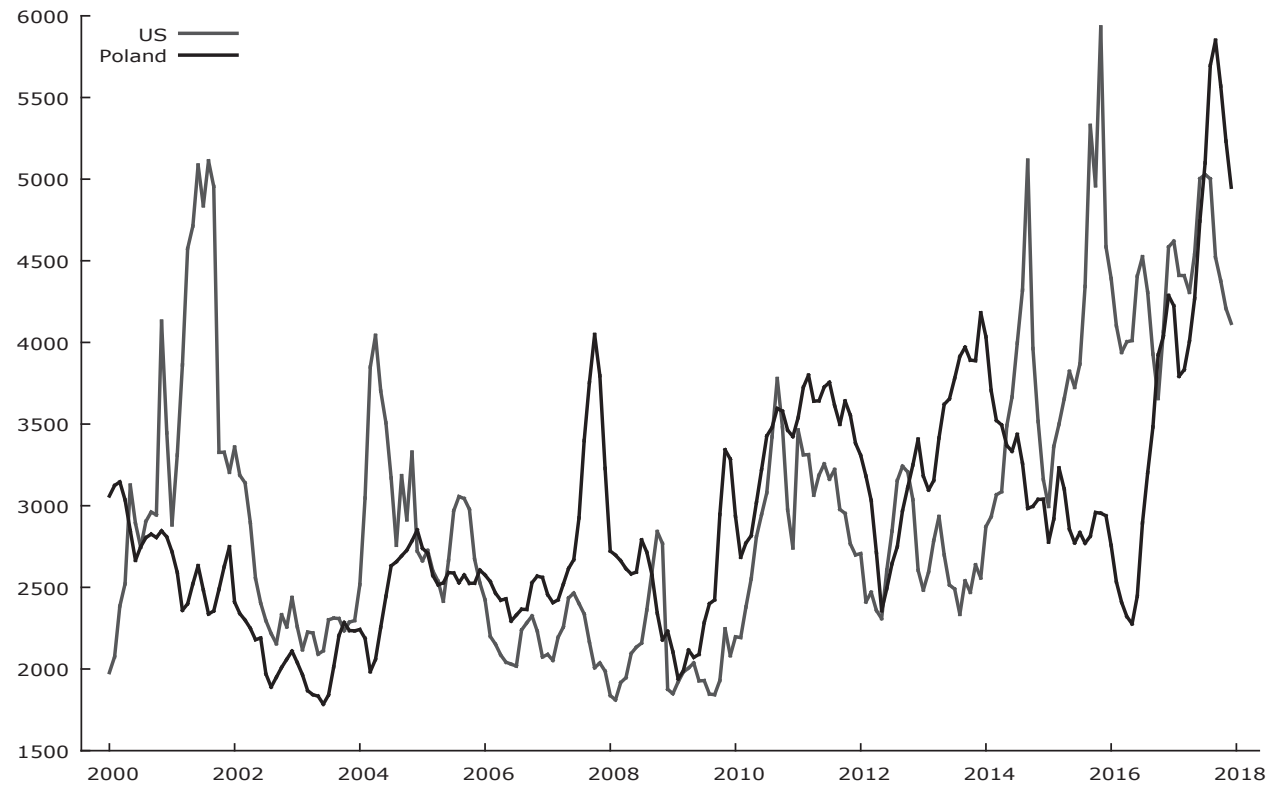

Fig. 2. Prices of butter in Poland and USA in 2000-2017 ( $€ /$ tons)

Source: own work based on (CLAL.IT, n.d.). 


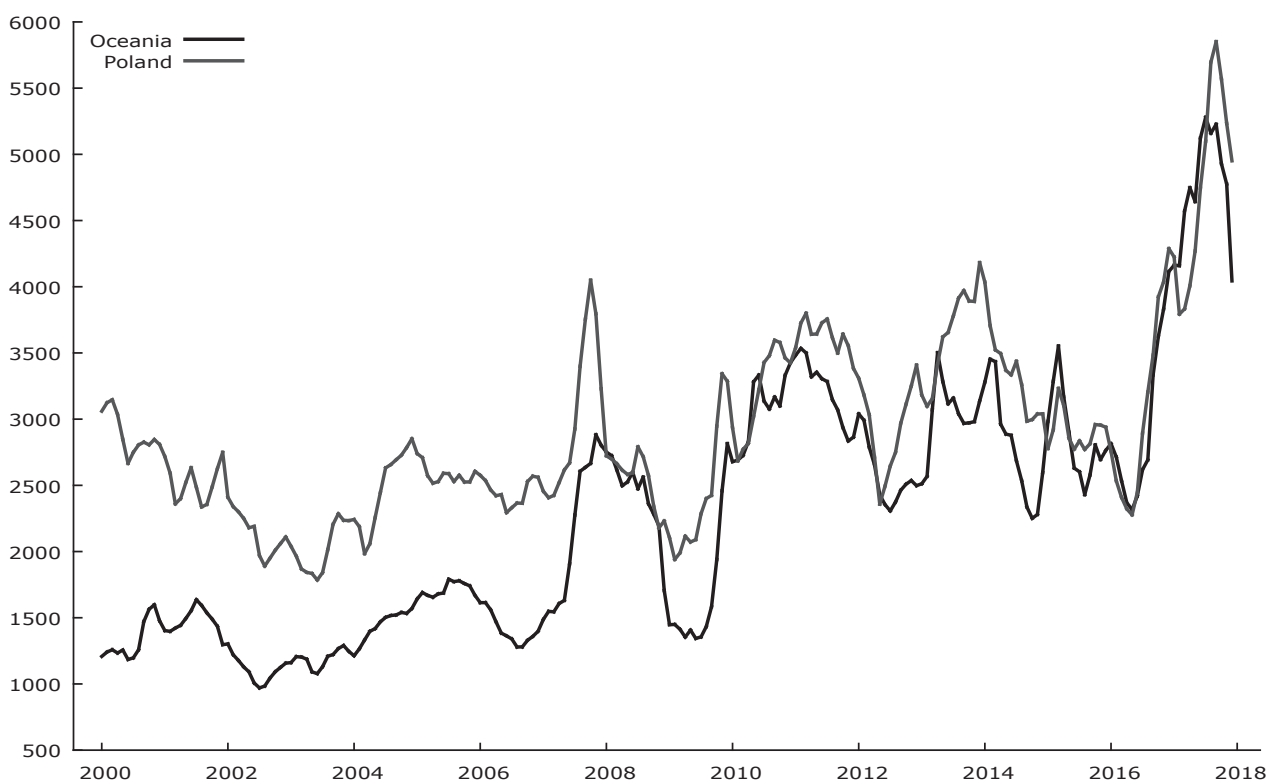

Fig. 3. Prices of butter in Poland and Oceania in 2000-2017 (€/tons)

Source: own work based on (CLAL.IT, n.d.).

Table 1. Results of the co-integration analysis between prices of butter in Poland an in Western Europe, USA and Oceania

\begin{tabular}{|c|c|c|c|c|c|c|c|c|}
\hline \multirow{3}{*}{ Region } & \multirow{3}{*}{$\mathbf{H}_{0}$} & \multirow{3}{*}{$\mathrm{H}_{1}$} & \multicolumn{2}{|c|}{ 2000-2017 } & \multicolumn{2}{|c|}{ 2000-2007 } & \multicolumn{2}{|c|}{ 2008-2017 } \\
\hline & & & trace test & $\begin{array}{c}\text { maximum } \\
\text { eigenvalue }\end{array}$ & trace test & $\begin{array}{l}\text { maximum } \\
\text { eigenvalue }\end{array}$ & trace test & $\begin{array}{l}\text { maximum } \\
\text { eigenvalue }\end{array}$ \\
\hline & & & $\begin{array}{c}\text { test } \\
\text { statistic } \\
{[p \text {-value }]}\end{array}$ & $\begin{array}{c}\text { test } \\
\text { statistic } \\
{[p \text {-value }]}\end{array}$ & $\begin{array}{c}\text { test } \\
\text { statistic } \\
\text { [p-value] }\end{array}$ & $\begin{array}{c}\text { test } \\
\text { statistic } \\
{[p \text {-value }]}\end{array}$ & $\begin{array}{c}\text { test } \\
\text { statistic } \\
{[p \text {-value }]}\end{array}$ & $\begin{array}{c}\text { test } \\
\text { statistic } \\
{[p \text {-value }]}\end{array}$ \\
\hline \multirow[t]{2}{*}{$\begin{array}{l}\text { Western } \\
\text { Europe }\end{array}$} & $r=0$ & $r=1$ & $\begin{array}{l}22.823 \\
{[0.132]}\end{array}$ & $\begin{array}{l}14.160 \\
{[0.253]}\end{array}$ & $\begin{array}{l}21.465 \\
{[0.162]}\end{array}$ & $\begin{array}{c}18.253 \\
{[0.071]}\end{array}$ & $\begin{array}{l}23.696 \\
{[0.090]}\end{array}$ & $\begin{array}{l}18.778 \\
{[0.059]}\end{array}$ \\
\hline & $r \leq 1$ & $r=2$ & $\begin{array}{c}8.103 \\
{[0.247]}\end{array}$ & $\begin{array}{c}8.143 \\
{[0.248]}\end{array}$ & $\begin{array}{c}3.212 \\
{[0.841]}\end{array}$ & $\begin{array}{c}3.212 \\
{[0.843]}\end{array}$ & $\begin{array}{c}4.918 \\
{[0.615]}\end{array}$ & $\begin{array}{c}4.918 \\
{[0.616]}\end{array}$ \\
\hline \multirow[t]{2}{*}{ USA } & $r=0$ & $r=1$ & $\begin{array}{l}24.109 \\
{[0.080]}\end{array}$ & $\begin{array}{l}18.322 \\
{[0.097]}\end{array}$ & $\begin{array}{l}22.387 \\
{[0.128]}\end{array}$ & $\begin{array}{l}18.957 \\
{[0.055]}\end{array}$ & $\begin{array}{l}19.197 \\
{[0.275]}\end{array}$ & $\begin{array}{c}11.817 \\
{[0.4450]}\end{array}$ \\
\hline & $r \leq 1$ & $r=2$ & $\begin{array}{c}6.796 \\
{[0.377]}\end{array}$ & $\begin{array}{c}6.796 \\
{[0.377]}\end{array}$ & $\begin{array}{l}3.4308 \\
{[0.815]}\end{array}$ & $\begin{array}{c}3.431 \\
{[0.817]}\end{array}$ & $\begin{array}{c}7.379 \\
{[0.316]}\end{array}$ & $\begin{array}{c}7.379 \\
{[0.316]}\end{array}$ \\
\hline \multirow[t]{2}{*}{ Oceania } & $r=0$ & $r=1$ & $\begin{array}{l}26.955 \\
{[0.000]}\end{array}$ & $\begin{array}{l}23.782 \\
{[0.001]}\end{array}$ & $\begin{array}{l}20.101 \\
{[0.225]}\end{array}$ & $\begin{array}{c}13.746 \\
[0.281]]\end{array}$ & $\begin{array}{l}16.389 \\
{[0.470]}\end{array}$ & $\begin{array}{c}10.310 \\
{[0.595]}\end{array}$ \\
\hline & $r \leq 1$ & $r=2$ & $\begin{array}{c}3.145 \\
{[0.075]}\end{array}$ & $\begin{array}{c}3.107 \\
{[0.075]}\end{array}$ & $\begin{array}{c}6.355 \\
{[0.427]}\end{array}$ & $\begin{array}{c}6.355 \\
{[0.428]}\end{array}$ & $\begin{array}{c}6.079 \\
{[0.461]}\end{array}$ & $\begin{array}{l}6.0785 \\
{[0.462]}\end{array}$ \\
\hline
\end{tabular}

Note: grey cells indicate cointegration at the significance level $\alpha=0.05$

Source: own work based on (CLAL.IT, n.d.). 
other researchers in the scope of the geographic reach of the butter market using the Elzinga-Hogarty method, in which Poland, together with Western European countries, constitutes a single market (Baran, 2019; Roman, 2017). The analysis also showed that after 2004, price of butter in Oceania was the Granger-cause of changes in the price in Poland (Table 2). Meanwhile, in the case of the price of butter in the USA, it was found that in the entire studied period there was no causality in relation to the price in Poland.

Table 2. Granger-Causality Tests

\begin{tabular}{|c|c|c|c|c|c|c|}
\hline \multirow[b]{2}{*}{$\begin{array}{l}\text { Hypothesis } \\
\text { tested }\end{array}$} & \multicolumn{2}{|c|}{$2000-2017$} & \multicolumn{2}{|c|}{ 2000-2007 } & \multicolumn{2}{|c|}{ 2008-2017 } \\
\hline & $\begin{array}{c}\text { Fisher- } \\
\text { Snedecor } \\
\text { test } \\
\text { [p-value] }\end{array}$ & $\begin{array}{c}\text { price } \\
\text { dependency } \\
\text { direction }\end{array}$ & $\begin{array}{c}\text { Fisher- } \\
\text { Snedecor } \\
\text { test } \\
{[p \text {-value }]}\end{array}$ & $\begin{array}{c}\text { price } \\
\text { dependency } \\
\text { direction }\end{array}$ & $\begin{array}{c}\text { Fisher- } \\
\text { Snedecor } \\
\text { test } \\
{[p \text {-value }]}\end{array}$ & $\begin{array}{c}\text { price } \\
\text { dependency } \\
\text { direction }\end{array}$ \\
\hline $\begin{array}{l}\text { Poland - } \\
\text { Western } \\
\text { Europe }\end{array}$ & $\begin{array}{c}0.635 \\
{[0.531]}\end{array}$ & $\mathrm{E} \rightarrow \mathrm{PL}$ & $\begin{array}{c}0.031 \\
{[0.969]}\end{array}$ & $\mathrm{E} \rightarrow \mathrm{PL}$ & $\begin{array}{c}2.806 \\
{[0.0650]}\end{array}$ & $\mathrm{E} \rightarrow \mathrm{PL}$ \\
\hline $\begin{array}{l}\text { Western } \\
\text { Europe } \\
\text { - Poland }\end{array}$ & $\begin{array}{l}16.883 \\
{[0.000]}\end{array}$ & & $\begin{array}{l}12.279 \\
{[0.000]}\end{array}$ & & $\begin{array}{c}7.824 \\
{[0.001]}\end{array}$ & \\
\hline Poland - USA & $\begin{array}{c}0.029 \\
{[0.972]}\end{array}$ & USA x PL & $\begin{array}{c}0.430 \\
{[0.652]}\end{array}$ & USA x PL & $\begin{array}{c}0.085 \\
{[0.968]}\end{array}$ & USA x PL \\
\hline USA - Poland & $\begin{array}{c}0.205 \\
{[0.815]}\end{array}$ & & $\begin{array}{c}2.753 \\
{[0.069]}\end{array}$ & & $\begin{array}{c}0.787 \\
{[0.504]}\end{array}$ & \\
\hline $\begin{array}{l}\text { Poland - } \\
\text { Oceania }\end{array}$ & $\begin{array}{c}4.420 \\
{[0.013]}\end{array}$ & $\mathrm{O} \leftrightarrow \mathrm{PL}$ & $\begin{array}{c}1.988 \\
{[0.143]}\end{array}$ & $\mathrm{O} \times \mathrm{PL}$ & $\begin{array}{c}2.659 \\
{[0.075]}\end{array}$ & $\mathrm{O} \rightarrow \mathrm{PL}$ \\
\hline $\begin{array}{l}\text { Oceania - } \\
\text { Poland }\end{array}$ & $\begin{array}{l}13.186 \\
{[0.000]} \\
\end{array}$ & & $\begin{array}{c}5.928 \\
{[0.004]}\end{array}$ & & $\begin{array}{c}7.337 \\
{[0.001]} \\
\end{array}$ & \\
\hline
\end{tabular}

$\mathrm{x}$ - no causality, $\leftrightarrow$ - unidirectional, $\rightarrow-$ bidirectional

Note: grey cells indicate Granger causality at the significance level $\alpha=0.05$.

Source: own work based on (CLAL.IT, n.d.).

As part of the in-depth studies concerning the links between butter prices in selected European countries and Poland, an analysis of price co-integration was conducted again, using trace statistics and maximum own value. In relation to the butter market in the period 2004-2017, the study found long-term links between Polish prices and all the analysed countries: Belgiumthe Czech Republic, Germany, Ireland, Latvia, the Netherlands, Slovakia, Italy and France (Table 3).

The determination of the directions of transmission of price impulses between the analysed EU countries was made based on the Granger causality tests. The analysis showed that the price of butter in Poland in the entire analysed period was affected by those in the Netherlands and Belgium. Regarding butter prices in Germany, Italy, Ireland and France, a bi-directional causality in relation to the price 
of butt in Poland was found. In turn, the prices in Poland were the Granger-cause of the price changes in Czechia, Slovakia and Latvia (Table 4). Prices in Poland had the biggest effect on changes of prices in Czechia $(F=34.6)$.

Table 3. Results of the co-integration analysis between butter prices in Poland an in selected EU countries in 2004-2017

\begin{tabular}{|c|c|c|c|c|}
\hline Country & $\mathbf{H}_{0}$ & $\mathbf{H}_{1}$ & $\begin{array}{c}\text { Trace test } \\
\text { test statistic } \\
\text { [p-value] }\end{array}$ & $\begin{array}{c}\text { Maximum eigenvalue test } \\
\text { test statistic } \\
{[p \text {-value }]}\end{array}$ \\
\hline \multirow[t]{2}{*}{ Belgium } & $r=0$ & $r=1$ & $\begin{array}{l}28.395 \\
{[0.022]}\end{array}$ & $\begin{array}{l}19.381 \\
{[0.048]}\end{array}$ \\
\hline & $r \leq 1$ & $r=2$ & $\begin{array}{c}9.014 \\
{[0.184]}\end{array}$ & $\begin{array}{c}9.014 \\
{[0.184]}\end{array}$ \\
\hline \multirow[t]{2}{*}{ Czech Republic } & $r=0$ & $r=1$ & $\begin{array}{l}29.562 \\
{[0.015]}\end{array}$ & $\begin{array}{l}21.211 \\
{[0.024]}\end{array}$ \\
\hline & $r \leq 1$ & $r=2$ & $\begin{array}{c}8.352 \\
{[0.231]}\end{array}$ & $\begin{array}{c}8.352 \\
{[0.231]} \\
\end{array}$ \\
\hline \multirow[t]{2}{*}{ Germany } & $r=0$ & $r=1$ & $\begin{array}{l}27.337 \\
{[0.030]} \\
\end{array}$ & $\begin{array}{r}18.460 \\
{[0.066]} \\
\end{array}$ \\
\hline & $r \leq 1$ & $r=2$ & $\begin{array}{c}8.877 \\
{[0.193]}\end{array}$ & $\begin{array}{c}8.877 \\
{[0.193]}\end{array}$ \\
\hline \multirow[t]{2}{*}{ Ireland } & $r=0$ & $r=1$ & $\begin{array}{l}33.724 \\
{[0.003]}\end{array}$ & $\begin{array}{c}24.551 \\
{[0.006]}\end{array}$ \\
\hline & $r \leq 1$ & $r=2$ & $\begin{array}{c}9.173 \\
{[0.174]}\end{array}$ & $\begin{array}{c}9.173 \\
{[0.174]}\end{array}$ \\
\hline \multirow[t]{2}{*}{ Latvia } & $r=0$ & $r=1$ & $\begin{array}{r}36.922 \\
{[0.001]} \\
\end{array}$ & $\begin{array}{r}28.706 \\
{[0.001]} \\
\end{array}$ \\
\hline & $r \leq 1$ & $r=2$ & $\begin{array}{c}8.216 \\
{[0.242]} \\
\end{array}$ & $\begin{array}{c}8.216 \\
{[0.242]}\end{array}$ \\
\hline \multirow[t]{2}{*}{ The Netherlands } & $r=0$ & $r=1$ & $\begin{array}{l}40.905 \\
{[0.000]}\end{array}$ & $\begin{array}{r}29.119 \\
{[0.001]}\end{array}$ \\
\hline & $r \leq 1$ & $r=2$ & $\begin{array}{r}11.786 \\
{[0.065]}\end{array}$ & $\begin{array}{c}11.786 \\
{[0.0649]}\end{array}$ \\
\hline \multirow[t]{2}{*}{ Slovakia } & $r=0$ & $r=1$ & $\begin{array}{r}34.492 \\
{[0.003]}\end{array}$ & $\begin{array}{l}24.283 \\
{[0.007]} \\
\end{array}$ \\
\hline & $r \leq 1$ & $r=2$ & $\begin{array}{c}10.209 \\
{[0.120]}\end{array}$ & $\begin{array}{c}10.209 \\
{[0.119]}\end{array}$ \\
\hline \multirow[t]{2}{*}{ Italy } & $r=0$ & $r=1$ & $\begin{array}{c}27.336 \\
{[0.030]} \\
\end{array}$ & $\begin{array}{r}18.932 \\
{[0.056]} \\
\end{array}$ \\
\hline & $r \leq 1$ & $r=2$ & $\begin{array}{c}8.403 \\
{[0.227]} \\
\end{array}$ & $\begin{array}{c}8.403 \\
{[0.227]} \\
\end{array}$ \\
\hline \multirow[t]{2}{*}{ France } & $r=0$ & $r=1$ & $\begin{array}{r}30.436 \\
{[0.011]} \\
\end{array}$ & $\begin{array}{c}21.558 \\
{[0.021]} \\
\end{array}$ \\
\hline & $r \leq 1$ & $r=2$ & $\begin{array}{c}8.878 \\
{[0.193]} \\
\end{array}$ & $\begin{array}{c}8.878 \\
{[0.193]} \\
\end{array}$ \\
\hline
\end{tabular}

Note - grey cells indicate cointegration at the significance level $\alpha=0.05$.

Source: own work based on (EU Milk Market Observatory). 
Table 4. Granger-Causality Tests

\begin{tabular}{|c|c|c|}
\hline Relations & $\begin{array}{c}\text { Fisher-Snedecor test } \\
{[p \text {-value }]}\end{array}$ & $\begin{array}{l}\text { Price dependency } \\
\text { direction }\end{array}$ \\
\hline Poland-Belgium & $\begin{array}{c}2.416 \\
{[0.069]}\end{array}$ & \multirow{2}{*}{ Belgium $\rightarrow$ Poland } \\
\hline Belgium -Poland & $\begin{array}{l}17.677 \\
{[0.000]}\end{array}$ & \\
\hline Polan-Czech Republic & $\begin{array}{l}34.581 \\
{[0.000]}\end{array}$ & \multirow{2}{*}{ Poland $\rightarrow$ Czech Republic } \\
\hline Czech Republic-Poland & $\begin{array}{c}2.071 \\
{[0.130]}\end{array}$ & \\
\hline Poland-Germany & $\begin{array}{c}4.258 \\
{[0.003]}\end{array}$ & \multirow{2}{*}{ Poland $\leftrightarrow$ Germany } \\
\hline Germany-Poland & $\begin{array}{c}7.519 \\
{[0.000]}\end{array}$ & \\
\hline Poland-Ireland & $\begin{array}{l}11.923 \\
{[0.000]}\end{array}$ & \multirow{2}{*}{ Poland $\leftrightarrow$ Ireland } \\
\hline Ireland-Poland & $\begin{array}{c}3.894 \\
{[0.010]}\end{array}$ & \\
\hline Poland-Latvia & $\begin{array}{l}12.909 \\
{[0.000]}\end{array}$ & \multirow{2}{*}{ Poland $\rightarrow$ Latvia } \\
\hline Latvia - Poland & $\begin{array}{c}0.437 \\
{[0.647]}\end{array}$ & \\
\hline Poland-The Netherlands & $\begin{array}{c}0.768 \\
{[0.548]}\end{array}$ & \multirow{2}{*}{$\begin{array}{c}\text { The Netherlands } \\
\rightarrow \text { Poland }\end{array}$} \\
\hline The Netherlands-Poland & $\begin{array}{l}7.347 \\
{[0.000]}\end{array}$ & \\
\hline Poland-Slovakia & $\begin{array}{l}11.688 \\
{[0.000]}\end{array}$ & \multirow{2}{*}{ Poland $\rightarrow$ Slovakia } \\
\hline Slovakia-Poland & $\begin{array}{c}1.549 \\
{[0.191]}\end{array}$ & \\
\hline Poland-Italy & $\begin{array}{l}13.414 \\
{[0.000]}\end{array}$ & \multirow{2}{*}{ Poland $\leftrightarrow$ Italy } \\
\hline Italy-Poland & $\begin{array}{l}8.648 \\
{[0.000]}\end{array}$ & \\
\hline Poland-France & $\begin{array}{l}13.069 \\
{[0.000]}\end{array}$ & \multirow{2}{*}{ Poland $\leftrightarrow$ France } \\
\hline France-Poland & $\begin{array}{l}6.597 \\
{[0.002]}\end{array}$ & \\
\hline
\end{tabular}

$\mathrm{x}-$ no causality, $\leftrightarrow$ unidirectional, $\rightarrow$ bidirectional

Note: grey cells indicate Granger causality at the significance level $\alpha=0.05$.

Source: own work based on (EU Milk Market Observatory). 


\section{Conclusion}

In the years 2000-2017, the difference between price of butter in Poland and in Western European countries and Oceania diminished. At the same time, however, there was an increase in the differences in relation to the American market. The obtained results confirmed the significant links between the price of butter in Poland and in Oceania and the selected EU countries. A co-integration analysis carried out for the period 2004-2017 confirmed the long-term link between the price of butter in Poland and those in Belgium, Czechia, Germany, France, Ireland, the Netherlands, Slovakia, Italy and Latvia, thus confirming the transnational spatial dimension of the market, similar to a flow-of-goods analysis. Therefore, the area of these countries should be treated as a single butter market.

Considering the fragmentary nature of the analysis, which only includes the dependencies of the price of butter for Poland, the next step should focus on an interdependence test of butter prices between all the countries. In addition, similar studies should be continued for other dairy products, because the situation on various markets of dairy products may indirectly affect the milk market, i.e. the raw material, but also the situation of the entire dairy sector in Poland.

The research has some limitations being based on the law of one price (LOP), which states that homogeneous goods will be sold in different markets at the same price, assuming perfect competition conditions and no transaction costs (transportation costs, customs and other trade restrictions. In fact there is no situation on the market when all of the above assumptions are met. For example, transportation costs depend on the distance travelled by goods from where they are made to the consumer. This means each butter production company would have to be considered as a separate market. Moreover, the law of one price is based on the assumptions of perfect competition, therefore it requires the fulfillment of the following conditions: numerous producers and consumers, homogeneous product, complete information, no barriers to entering the market. The consumers do not have complete information and do not have to behave rationally. In addition, consumer choices are influenced by other factors such as delivery time and punctuality, which may counteract the uniformity of prices. There may also be trade restrictions on the butter market, such as embargoes. The exchange rate can also affect the research results.

One should note that the methods which are based on the time series of prices have their weaknesses, e.g. the selection of the analysed period; the obtained results may differ depending on the length of the time series and the adopted period of analysis; additionally, apparent links and accidental relations between prices may occur. Moreover the study has limitations due to the Common Agricultural Policy within the European Union, which has a significant impact on the shaping of prices of agricultural products. Therefore, research based on price links between markets should be supplemented by studies based on the flow of goods. 


\section{References}

Baffes, J., and Bruce, G. (2003). The transmission of world commodity prices to domestic markets under policy reforms in developing countries. Policy Reform, (6), 159-180.

Bakucs, Z., Fałkowski, J., and Fertö, I. (2010). Milk Market Integration between Hungary and Poland (84th Annual Conference, March 29-31, 2010, Edinburgh, Scotland, Agricultural Economics Society). Retrieved March, 30, 2016 from http://ageconsearch.umn.edu/bitstream/91809/2/74 Bakucs falkowski_ferto.pdf

Baran, J. (2019). Intensywność i zasięg geograficzny internacjonalizacji sektora przetwórstwa mleka. Warszawa: Wydawnictwo SGGW.

Baulch, B. (1997). Transfer costs, spatial arbitrage, and testing for food market integration. American Journal of Agricultural Economics, 79(2), 477-487

CLAL.IT. (n.d.). Retrieved from https://www.clal.it

Charemza, W., and Deadman, D. (1997). Nowa ekonometria. Warszawa: PWE.

Czapla, E. (2010). Powiązania długookresowe między stopami procentowymi Polski, Stanów Zjednoczonych i strefy euro. Zeszyty Naukowe Instytutu Ekonomii i Zarzadzania, (14), 265-275.

Domagała, J. (2019). Zakres procesów internacjonalizacji na rynku serów. Journal of Tourism and Regional Development, (11), 13-22. doi 10.22630/TIRR.2019.11.2

Domagała, J. (2020). Links between SMP prices in Poland and selected foreign markets. Annals PAAAE, XXII(4), 44-52. doi: 10.5604/01.3001.0014.4930

EU Milk Market Observatory. Retrieved from https://ec.europa.eu/info/food-farming-fisheries/farming/facts-and-figures/markets/overviews/market-observatories/milk_pl)

Fousekis, P., Emmanouilides, C., and Grigoriadis, V. (2016). Price linkages in the international skim milkpowder market: Empirical evidence from nonparametric and time-varying copulas. Australian Journal of Agricultural and Resource Economics, (61), 135-153.

Fousekis, P., and Trachanas, E. (2016). Price transmission in the international skim milk powder markets. Applied Economics, 48(54), 5233-5245.

Hamulczuk, M. (2007). Powiązania cen wieprzowiny pomiędzy rynkiem polskim, duńskim i niemieckim. Problemy Rolnictwa Światowego, 2(17), 195-206.

Hamulczuk, M., Gędek S., Klimkowski, C., and Stańko, S. (2012). Prognozowanie cen surowców rolnych na podstawie zależności przyczynowych. Warszawa: IERiGŻ-PIB.

Hamulczuk, M., and Klimkowski, C. (2011), Powiązania między cenami ropy a cenami pszenicy w Polsce. Roczniki Nauk Rolniczych - Seria G, Ekonomika Rolnictwa, 98(3), 176-190.

Jha, A. K., Singh, K. M., and Singh, R. K. P. (2012). Market integration in wholesale milk markets in India. Social Science Research Network, (May), 1-12. doi: 10.2139/ssrn.2062821

Katrakilidis, C. (2008). Testing for market integration and the law of one price: An application to selected European milk markets. International Journal of Economic Research, 5(1), 93-104.

Krawiec, M. (2013). Badanie przyczynowości w sensie Grangera na rynku zbóż w Polsce w latach 2007-2011. Zagadnienia Ekonomiki Rolnej, (1), 60-72.

Massey, P. (2000). Market definition and market power in competition analysis: Some practical issues. The Economic and Social Review, 31(4), 309-329.

Mickiewicz, T. (2012). Wybór w gospodarce. Wprowadzenie do ekonomii. Kraków-Rzeszów-Zamość: Wydawnictwo WSE w Krakowie, WSIiZ w Rzeszowie, WSIiZ w Zamościu.

Office for Competition and Consumer Protection. (2014). Decyzja $n r$ DKK2-420/3/13/MIW. Warszawa: Urząd Ochrony Konkurencji i Konsumentów.

Rembeza, J. (2009). Powiązania pomiędzy cenami produktów rolnych w Polsce i krajach UE. Zeszyty Naukowe Szkoły Głównej Gospodarstwa Wiejskiego w Warszawie. Problemy Rolnictwa Światowego, 7(22), 111-119. 
Rembeza, J., and Chotkowski, J. (2006). Powiązanie cen produktów rolnych pomiędzy rynkiem polskim a rynkami UE. Zeszyty Naukowe Szkoty Gtównej Gospodarstwa Wiejskiego w Warszawie. Problemy Rolnictwa Światowego, (15), 198-204.

Rembeza, J., Seremak-Bulge, J., and Hryszko, K. (2005). Ceny, ich relacje oraz transmisja na rynku mleka. W: J. Seremak-Bulge (red.), Rozwój rynku mleczarskiego i zmiany jego funkcjonowania w latach 1990-2005 (pp. 177-212).Warszawa: IERiGŻ-PIB.

Roman, M. (2017). Powiązanie cen masła między rynkiem polskim a wybranymi rynkami krajów Unii Europejskiej. Roczniki Naukowe SERiA XIX, (4), 169-174. doi: 10.5604/01.3001.0010.5182

Seremak-Bulge, J., and Roman M. ( 2016). Sytuacja na światowym rynku mleka i jej wpływ na polski rynek i jego możliwości rozwojowe. W: S. Stańko (red.), Sytuacja na światowych rynkach mięsa i produktów mleczarskich oraz jej wptyw na rynek krajowy i możliwości jego rozwoju (pp. 105-154). Warszawa: IERiGŻ-PIB.

Szajner, P. (2017). Transmisja cen na rynku mleka w Polsce w latach 2004-2017. Zagadnienia Ekonomiki Rolnej, 4(353), 3-23.

Werden, G. J., and Froeb, L. (1993). Correlation, casuality and all that jazz: The inherent shortcomings of price tests for antitrust market delineation. Review of Industrial Organization, (8), 329-353.

Zhang, J., Brown, C., Dong, X., and Waldron, S. (2017). Price transmission in whole milk powder markets: implications for the Oceania dairy sector of changing market developments. New Zealand Journal of Agricultural Research, 60(2), 140-153. doi: 10.1080/00288233.2017.1284133

\section{POWIAZZANIE CEN MASLA W POLSCE Z WYBRANYMI RYNKAMI ŚWIATA}

Streszczenie: Celem artykułu jest określenie powiązań między cenami masła w Polsce a cenami masła w wybranych krajach. Wykorzystano dane wtórne dotyczące miesięcznych cen masła na poziomie państw, gromadzone przez EU Milk Market Observatory oraz portal CLAL.IT za lata 2000-2017. Analizowany okres podzielono na dwa podokresy: 2000-2007 i 2008-2017. Do analizy powiązań zastosowano testy kointegracji Johansena oraz analizę przyczynowości Grangera. W pierwszym etapie badań przeanalizowano powiązania między ceną masła w Polsce a cenami w Europie Zachodniej, USA i Oceanii. W ramach drugiego etapu badań przeanalizowano powiązania między cenami masła w Polsce i w wybranych krajach UE. Uzyskane wyniki badań potwierdziły silniejsze powiązanie cen masła w Polsce z cenami masła w Europie Zachodniej i Oceanii, szczególnie w drugim podokresie, czyli po globalnym kryzysie finansowym. Biorąc pod uwagę ceny w UE, należy stwierdzić, że największe powiązania z cenami masła w Polsce miały ceny w Belgii, Czechach, Niemczech, Irlandii oraz Holandii.

Słowa kluczowe: rynek masła, ceny, analiza szeregów czasowych. 